\title{
Increasing Mortality From Pulmonary Embolism in Japan, 1951-2000
}

\author{
Masahito Sakuma, MD; Yuji Konno, MD; Kunio Shirato, MD
}

\begin{abstract}
In the United States, annual mortality rates from pulmonary embolism (PE) tended to increase from the 1960s to the mid 1980s, but thereafter began to decrease. In Japan, PE is not yet widespread and there have not been any reports of the time-trend of its mortality rate. The present study calculated the annual age-adjusted and agespecific PE mortality rates for Japanese residents during 1951 to 2000 from the 'Vital Statistics of Japan' and the census data and population estimates for the intercensal years. Throughout the study period, the age-adjusted deaths and mortality rates from PE continued to increase, and between 1976 and 1996 the increases in the annual age-specific mortality rates were substantial in males $45-49$ years of age and 55 years or older, and in females 30 years of age or older. The age-specific PE death rates increased throughout the life span in general and according to the decade. Male mortality was greater at most ages. In Poisson regression analysis, the relative risk of death from PE was increased in males, the aged, and in recent years. Overall, mortality from PE in Japan increased significantly during 1951 to 2000 . (Circ J 2002; 66: 1144-1149)
\end{abstract}

Key Words: Cardiovascular disease; Mortality; Pulmonary circulation; Pulmonary embolism

$\mathbf{P}$ ulmonary embolism (PE) has not yet become widespread in Japan. The number of patients with PE per year is estimated at more than 600,000 in the United States, whereas in 1996 in Japan there were only approximately 3,500 cases? In the US, annual mortality rates from PE tended to increase from the 1960 s to the mid $1980 \mathrm{~s}$, but thereafter began to decrease. In Japan, routine autopsy examinations have revealed that the deaths from PE have been increasing ${ }^{5-7}$ but there has not been a report of the time-trend of the mortality rate of PE. The present study examined the annual change in the mortality rate and compared the Japanese data with those from the US.

\section{Methods}

Data on deaths and population for the period 1951-2000 were obtained from the 'Vital statistics of Japan', census data? and population estimates for the intercensal years $1^{0}$ The register is based on death certificates issued by doctors. These data were reviewed for deaths in which PE was coded as the underlining cause (for 1951-67 ICD-7, rubric 465; for 1968-78 ICD-8, rubric 450; for 1979-94 ICD-9 rubric 415.1; for 1995-2000 ICD-10, rubric I26). The annual age-adjusted deaths and mortality rates by gender, using the 1985 Japan population as the standard, which is the common method in Japanese epidemiology, were obtained for each year from 1951 through 2000. For these calculations, we used 5-year step populations up to 85 years old and those 85 or older as the population data in each year. However, because the population of those from 80 to 84 years old was not described separately during 1951 to 1954, we used 5-year step populations up to 80 years old

(Received June 3, 2002; revised manuscript received August 28, 2002; accepted September 2, 2002)

Department of Cardiovascular Medicine, Tohoku University Graduate School of Medicine, Sendai, Japan

Mailing address: Kunio Shirato, Department of Cardiovascular Medicine, Tohoku University Graduate School of Medicine, 1-1 Seiryo-machi, Aoba-ku, Sendai 980-8575, Japan and the population of 80 or older as the population data in those years. Moreover, the number of PE patients (ICD-9 rubric 415.1) was reported separately from that of other acute pulmonary heart diseases (ICD-9 rubric 415.0) in total, but not by age during 1979 to 1994 . In order of years from 1979 to 1994 , the number of other acute pulmonary heart diseases in males was 8, 2, 0, 5, 6, 6, 1, 3, 1, 3, 2, 1, 3, 4, 3 and 3, respectively; and in females, 3, 5, 7, 3, 2, 0, 1, 3, $0,1,0,1,1,1,2$ and 2 . Therefore, the annual age-adjusted deaths and mortality rates from PE includeed those from other acute pulmonary heart diseases in those years.

The annual age-specific mortality rates in Japan by gender were generated using the same resources ${ }^{8-120}$ and the percentage changes from 1979 to 1996 in the age-genderspecific rates were calculated. The data in those years were selected for comparison with the data in the report by Lilienfeld ${ }^{4}$ who examined the mortality from PE in the United States.

The percent changes from 1979 to 1996 in the agegender-specific rates were analyzed using the standard $\mathrm{z}-$ test ${ }^{121}$ For 2 Poisson regression analyses, ${ }^{122}$ we used the GENMOD procedure (generalized linear models) in SAS for Windows version 6.12 (SAS Institute, Cary, NC, USA). One was fitted for the calendar year on age-adjusted PE deaths; that is: $\ln$ (age-adjusted deaths) $=\alpha+\beta *$ (calendar year), where the calendar year was given as $1,2, \ldots 50$ (year 1 is 1951, year 2 is 1952, and so on to 2000). Another Poisson regression was fitted for each gender, calendar year and 5 -year age group on PE mortality; that is: $\ln$ (deaths) $=\ln$ (population size) $+\alpha+\beta 1 *$ (gender) $+\beta 2 *$ (calendar year in decade $)+\beta 3 *(10$-year age group). The reference categories were male, the 1951-60 period and the under 20 years age group. These results were summarized by presenting the relative risk of PE.

\section{Results}

The age-adjusted deaths and mortality rates from PE are tabulated in 10-year steps from 1956 to 1996 in Table 1 and 
Table 1 Annual-Adjusted Pulmonary Embolism Mortality per 100,000 Parsons by Gender

\begin{tabular}{lccccc}
\hline \hline & 1956 & 1966 & 1976 & 1986 & 1996 \\
\hline Male & $0.10(44)$ & $0.13(62)$ & $0.21(117)$ & $0.36(218)$ & $0.71(439)$ \\
Female & $0.07(30)$ & $0.07(37)$ & $0.12(69)$ & $0.37(228)$ & $0.83(531)$ \\
All & $0.08(75)$ & $0.10(99)$ & $0.16(185)$ & $0.37(446)$ & $0.77(970)$ \\
\hline
\end{tabular}

Adjusted to the 1985 Japanese population. Numbers in pacentheses are the number of annual age-adjusted deaths.
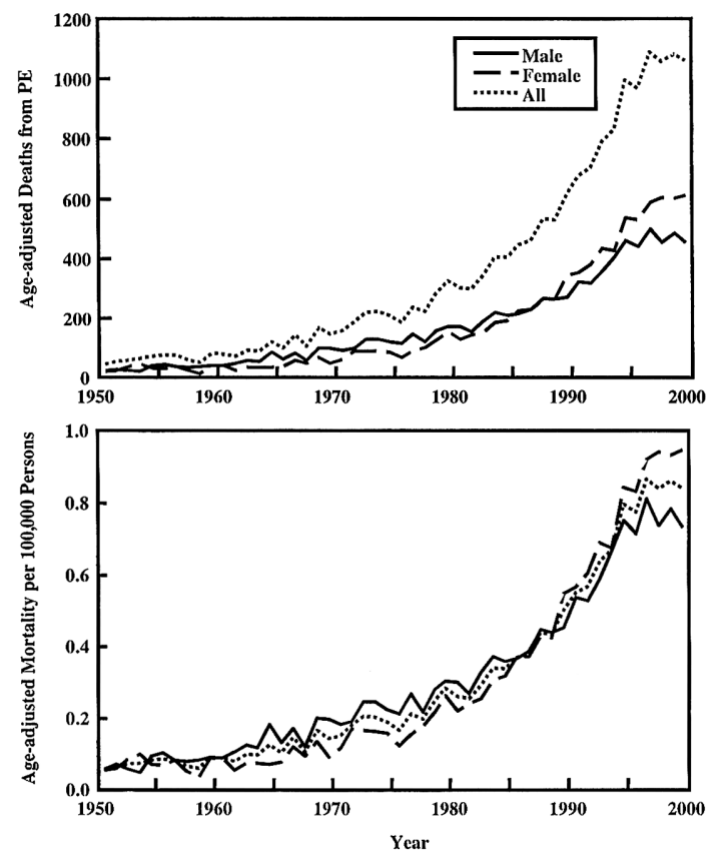

Fig 1. Annual age-adjusted pulmonary embolism (PE) deaths and mortality rates by gender, 1951-2000.

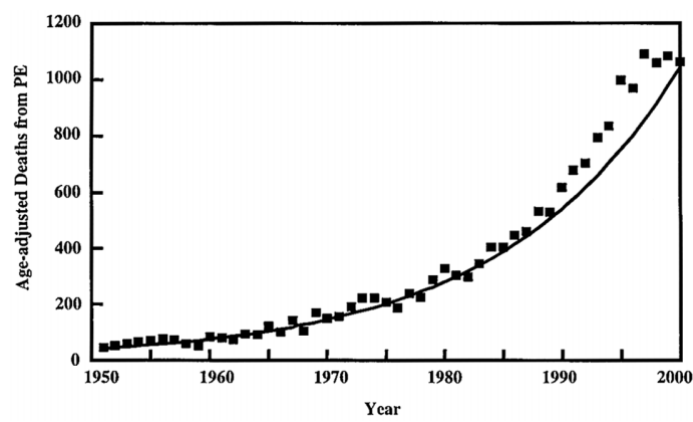

Fig 2. Annual age-adjusted pulmonary embolism (PE) deaths with Poisson regression during 1951-2000. $\ln y=\alpha+\beta \times(\alpha=3.6535,95 \%$ confidence interval: $3.6017-3.7052 ; \mathrm{p}<0.0001$ and $\beta=0.0689,95 \%$ CI: 0.0676-0.0703; $\mathrm{p}<0.0001$ ).

it can be seen that they continue to increase in Japan (Fig 1). The annual age-adjusted PE mortality rates markedly increased in both genders in every decade and in the 1980s, women exceeded men in age-adjusted deaths and mortality rates. The age-adjusted mortality rates in Japan during 1951to 2000 are shown in Fig 2, together with the fitting curve, the slope of which $\beta$ ) was positive and statistically significant at the 0.0001 level.

The changes in the annual age-specific PE mortality rates in Japan between 1979 and 1996 by gender are shown in Table 2 and it can be seen that the increases in the rates
Table 2 Percentage Change in Annual Age-Specific Pulmonary Embolism Mortality in Japan Between 1979 and 1996 by Gender

\begin{tabular}{ccc}
\hline \hline Age (years) & Male & Female \\
\hline $0-4$ & + & + \\
$5-9$ & + & + \\
$10-14$ & + & + \\
$15-19$ & + & -2 \\
$20-24$ & + & $23^{*}$ \\
$25-29$ & 1 & + \\
$30-34$ & 151 & $283^{*}$ \\
$35-39$ & 179 & $266^{*}$ \\
$40-44$ & 140 & $873^{* * *}$ \\
$45-49$ & $145^{*}$ & $143^{*}$ \\
$50-54$ & 9 & $225^{* *}$ \\
$55-59$ & $214^{* *}$ & $1,513^{* * *}$ \\
$60-64$ & $242^{* * *}$ & $155^{* * *}$ \\
$65-69$ & $218^{* * *}$ & $237^{* * *}$ \\
$70-74$ & $106^{* * *}$ & $350^{* * *}$ \\
$75-79$ & $140^{* * *}$ & $491 * * *$ \\
$80-84$ & $272^{* * *}$ & $253^{* * *}$ \\
$85-$ & $349 * * *$ & $477^{* * *}$ \\
\hline
\end{tabular}

+ , Rate in 1979 was 0 deaths per 100,000 persons. ${ }^{*} p<0.05, * * p<0.01, * * * p<0.001$.
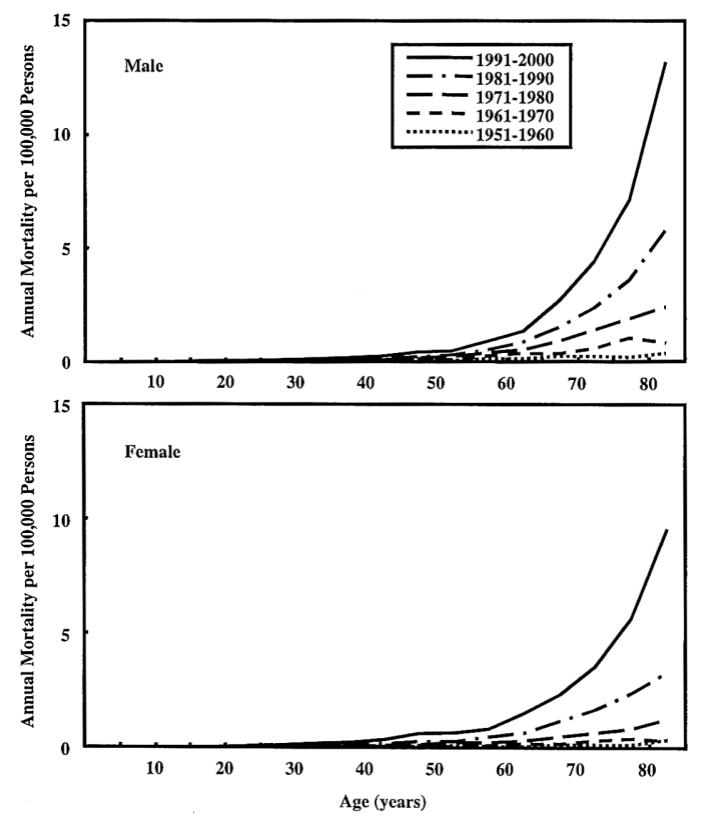

Fig 3. Age-specific pulmonary embolism mortality rates in Japan, by gender, in 5 decades.

were substantial in males 45-49 years old and in those 55 years or older, as they were in females 20-24 years old and in those 30 years or older. The age-specific PE death rates in Japan in 5 decades are shown in Fig 3; generally, the rates increased throughout the life span and according to the decade, but male mortality was greater than that of 
Table 3 Ralative Risk of Pulmonary Embolism Mortality Calculated by Poisson Regression

\begin{tabular}{lccc}
\hline \hline & Ralative risk & 95\% confidence interval & $p$ value \\
\hline Male & 1.00 & & \\
Female & 0.80 & $0.78-0.82$ & $<0.0001$ \\
$1951-60$ & 1.00 & & \\
$1961-70$ & 1.55 & $1.36-1.77$ & $<0.0001$ \\
$1971-80$ & 2.85 & $2.54-3.20$ & $<0.0001$ \\
$1981-90$ & 5.35 & $4.80-5.98$ & $<0.0001$ \\
$1991-2000$ & 11.48 & $10.31-12.79$ & $<0.0001$ \\
Age group & & & \\
$<20$ & 1.00 & & $<0.0001$ \\
$20-24$ & 3.28 & $2.61-4.11$ & $<0.0001$ \\
$25-29$ & 5.79 & $4.73-7.09$ & $<0.0001$ \\
$30-34$ & 7.07 & $5.81-8.61$ & $<0.0001$ \\
$35-39$ & 8.45 & $6.98-10.23$ & $<0.0001$ \\
$40-44$ & 13.42 & $11.22-16.05$ & $<0.0001$ \\
$45-49$ & 21.85 & $18.41-25.94$ & $<0.0001$ \\
$50-54$ & 24.34 & $20.51-28.88$ & $<0.0001$ \\
$55-59$ & 38.84 & $32.85-45.93$ & $<0.0001$ \\
$60-64$ & 60.83 & $51.56-71.77$ & $<0.0001$ \\
$65-69$ & 103.11 & $87.57-121.41$ & $<0001$ \\
$70-74$ & 160.52 & $136.41-188.88$ & \\
$75-79$ & 249.44 & $212.05-293.42$ & \\
$>79$ & 417.76 & $355.67-490.73$ & \\
\hline
\end{tabular}

females at most ages.

In Poisson regression analysis, the relative risk of $\mathrm{PE}$ mortality was elevated in males, the aged, and in recent years (Table 3 ).

\section{Discussion}

There are various reasons why the age-adjusted mortality rates from PE are rapidly increasing in Japan. First is the improvement in correct diagnosis of the disease, which has also been described as a cause of the increment in the mortality rates from PE in the United States from the 1960s to the mid 1980s. The clinically diagnosed rate in autopsy cases in which PE is the main diagnosis or cause of death increased from $28.7 \%$ in 1987 to $45.3 \%$ in 1997 in Japan, which supports this hypothesis? Second is the Westernization of life style in Japan, including diet. Based on 'The national nutrition survey in Japan',23 energy intake from both fish and meat, lipids and vegetables has been increasing, but that from cereal and the consumption of fish compared with meat has been decreasing. Physically, the body mass index has increased in recent years. Moreover, the number of patients suffering from hyperlipidemia has increased ${ }^{124}$ and some reports have described hyperlipidemia as a risk factors for venous thromboembolism. ${ }^{125,126} \mathrm{de}$ Lorgeril et el indicated that PE after myocardial infarction occurred in 0/219 of patients with a Mediterranean-type diet, but in $3 / 204$ patients with a prudent Western-type diet 127 However, it remains to be determined how much these changes in life style influence the occurrence of PE.

The age-specific mortality rate from $\mathrm{PE}$ is increasing year by year in Japan (Fig 3) and moreover, the frequency has been increasing with age. Furthermore, our Poisson regression analysis showed that the relative risk of PE mortality is elevated in males, the aged, and in recent years. An agedependent elevation in the mortality rate has been seen in Western countries ${ }^{3,4}$ and resembles the clinical data in Japan described by Kumasaka et al ${ }^{128}$ and Nakamura et al ${ }^{129}$

In Japan, the increment of cases with PE is clear not only in the mortality rate shown in the present study, but also in autopsy examinations ${ }^{5-7}$ and clinical studies? ${ }^{2,130}$ In clinical examinations, the number of cases with PE increased from 3,492 (95\% confidence interval (CI): 3,280-3,703) in $1996^{2}$ to 4,020 (95\% CI: $3,704-4,305)$ in 2000130

As shown in Table 2, the mortality rate from PE increased particularly in elderly persons in Japan when comparing the data from 1979 with those of 1996. In contrast, Lilienfeld showed that in the US the mortality rate declined among all ages and race groups during the same period. The risk factors for PE in Japan are similar to those in Western countries, ${ }^{128-130}$ but high-risk patients commonly receive prophylaxis in the West, which is less usual in Japan where there are no guidelines on prophylaxis for PE and each doctor must make the decision for individual cases. Differences in the use of prophylaxis for PE between Japan and Western countries may have influenced the trend of the mortality rate.

Age-adjusted mortality rates and age-specific mortality rates in 1996 were similar between Japanese in our study and non-black non-white Americans reported by Lilienfeld. The similarity was only a transient result of the accelerated elevation of mortality rates in Japan and the decline of mortality rates in the US. This comparison and the data on the number of clinical cases in Japan 2,130 and the United States $^{1}$ make the problem of the clinical diagnosis rate in Japan obvious, although a direct comparison with the ageadjusted mortality rates in the US cannot be accepted strictly because the standardized populations differ between the 2 countries.

The mortality rates from PE in Japan are increasing, but are still lower than in Western countries. Lilienfeld ${ }^{4}$ and Klatsky et $\mathrm{al}^{21}$ reported that mortality rates from PE were less frequent in non-black non-white than in black or white subjects and it appears that PE is not so usual in Mongoloid compared with Caucasian or black people. There are some differences in the hereditary risks for PE; for example, factor V Leiden and Prothrombin G20210A mutation, which are common in Western countries, ${ }^{132,133}$ have not been reported yet in the Japanese population! 132,135

The age-adjusted mortality rates from $\mathrm{PE}$ in females exceeded those in males in Japan in the 1980s, but the agespecific mortality rates in males are still higher than in females. The ratio of individuals 60 (70) years or older in the female population was 16.9 (8.1) \% and in males 12.6 (5.6) \% in 1985, which is the standard year used in Japan. Therefore, the differences between the age-adjusted and the age-specific mortality rates might be partly a result of gender differences in the population because more of the elderly subjects were female than male.

\section{Conclusions}

To date, there have been no reports on the trend of ageadjusted and age-specific mortality rates from PE in Japan and the results of the present study and their comparison with data with US studies were revealing. Age-adjusted mortality rates from $\mathrm{PE}$ are increasing and in females exceeded those of males in the 1980s. The relative risk of PE mortality is elevated in males, the aged, and in recent years. In 1996, the age-adjusted mortality rates in Japan were similar to those of non-black non-whites in the United States, resulting from the incremental trend of age-adjusted mortality rates in Japan and the decremental rates in the United States. 


\section{References}

1. Bell WR. Pulmonary embolism: Progress and problems. Am J Med 1982; 72: $181-183$.

2. Kumasaka N, Sakuma M, Shirato K. Incidence of pulmonary thromboembolism in Japan. Jpn Circ J 1999; 63: 439-441.

3. Lilienfeld DE, Chan E, Ehland J, Godbold JH, Landrigan PJ, Marsh G. Mortality from pulmonary embolism in the United States: 1962 to 1984 . Chest 1990; 98: 1067-1072.

4. Lilienfeld DE. Decreasing mortality from pulmonary embolism in the United States, 1979-1996. Int J Epidemiol 2000; 29: 465-469.

5. Hasegawa $H$, Nagata $H$, Yamauchi M, Murakoshi T, Oguma $Y$, Takei H, et al. Statistical status of pulmonary embolism in Japan (II). Jpn J Chest Dis 1981; 40: 677-681 (in Japanese).

6. Mieno T, Kitamura S. Incidence of pulmonary thromboembolism in Japan. Kokyu to Junkan 1989; 37: 923 -927 (in Japanese).

7. Sakuma M, Takahashi T, Kitamukai O, Shirato K, Nakamura M, Yazu T, et al. Incidence of pulmonary embolism in Japan: Analysis using 'Annual of the pathological autopsy cases in Japan'. Ther Res 2002; 23: 632-634 (in Japanese).

8. Statistics and Information Department, Minister's Secretariat, Ministry of Health, Labor and Welfare. Vital statistics of Japan. Tokyo, 1952.

9. Statistics and Information Department, Minister's Secretariat, Ministry of Health, Labor and Welfare. Vital statistics of Japan. Tokyo, 1953.

10. Statistics and Information Department, Minister's Secretariat, Ministry of Health, Labor and Welfare. Vital statistics of Japan. Tokyo, 1954.

11. Statistics and Information Department, Minister's Secretariat, Ministry of Health, Labor and Welfare. Vital statistics of Japan. Tokyo, 1955.

12. Statistics and Information Department, Minister's Secretariat, Ministry of Health, Labor and Welfare. Vital statistics of Japan. Tokyo, 1956.

13. Statistics and Information Department, Minister's Secretariat, Ministry of Health, Labor and Welfare. Vital statistics of Japan. Tokyo, 1957.

14. Statistics and Information Department, Minister's Secretariat, Ministry of Health, Labor and Welfare. Vital statistics of Japan. Tokyo, 1958.

15. Statistics and Information Department, Minister's Secretariat, Ministry of Health, Labor and Welfare. Vital statistics of Japan. Tokyo, 1959.

16. Statistics and Information Department, Minister's Secretariat, Ministry of Health, Labor and Welfare. Vital statistics of Japan. Tokyo, 1960.

17. Statistics and Information Department, Minister's Secretariat, Ministry of Health, Labor and Welfare. Vital statistics of Japan. Tokyo, 1961.

18. Statistics and Information Department, Minister's Secretariat, Ministry of Health, Labor and Welfare. Vital statistics of Japan. Tokyo, 1962.

19. Statistics and Information Department, Minister's Secretariat, Ministry of Health, Labor and Welfare. Vital statistics of Japan. Tokyo, 1963.

20. Statistics and Information Department, Minister's Secretariat, Ministry of Health, Labor and Welfare. Vital statistics of Japan. Tokyo, 1964.

21. Statistics and Information Department, Minister's Secretariat, Ministry of Health, Labor and Welfare. Vital statistics of Japan. Tokyo, 1965.

22. Statistics and Information Department, Minister's Secretariat, Ministry of Health, Labor and Welfare. Vital statistics of Japan. Tokyo, 1966.

23. Statistics and Information Department, Minister's Secretariat, Ministry of Health, Labor and Welfare. Vital statistics of Japan. Tokyo, 1967

24. Statistics and Information Department, Minister's Secretariat, Ministry of Health, Labor and Welfare. Vital statistics of Japan. Tokyo, 1968.

25. Statistics and Information Department, Minister's Secretariat, Ministry of Health, Labor and Welfare. Vital statistics of Japan. Tokyo, 1969.

26. Statistics and Information Department, Minister's Secretariat, Ministry of Health, Labor and Welfare. Vital statistics of Japan. Tokyo, 1970.

27. Statistics and Information Department, Minister's Secretariat, Ministry of Health, Labor and Welfare. Vital statistics of Japan. Tokyo, 1971.
28. Statistics and Information Department, Minister's Secretariat, Ministry of Health, Labor and Welfare. Vital statistics of Japan. Tokyo, 1972.

29. Statistics and Information Department, Minister's Secretariat, Ministry of Health, Labor and Welfare. Vital statistics of Japan. Tokyo, 1973.

30. Statistics and Information Department, Minister's Secretariat, Ministry of Health, Labor and Welfare. Vital statistics of Japan. Tokyo, 1974.

31. Statistics and Information Department, Minister's Secretariat, Ministry of Health, Labor and Welfare. Vital statistics of Japan. Tokyo, 1975 .

32. Statistics and Information Department, Minister's Secretariat, Ministry of Health, Labor and Welfare. Vital statistics of Japan. Tokyo, 1976.

33. Statistics and Information Department, Minister's Secretariat, Ministry of Health, Labor and Welfare. Vital statistics of Japan. Tokyo, 1977.

34. Statistics and Information Department, Minister's Secretariat, Ministry of Health, Labor and Welfare. Vital statistics of Japan. Tokyo, 1978

35. Statistics and Information Department, Minister's Secretariat, Ministry of Health, Labor and Welfare. Vital statistics of Japan. Tokyo, 1979 .

36. Statistics and Information Department, Minister's Secretariat, Ministry of Health, Labor and Welfare. Vital statistics of Japan. Tokyo, 1980.

37. Statistics and Information Department, Minister's Secretariat, Ministry of Health, Labor and Welfare. Vital statistics of Japan. Tokyo, 1981.

38. Statistics and Information Department, Minister's Secretariat, Ministry of Health, Labor and Welfare. Vital statistics of Japan. Tokyo, 1982.

39. Statistics and Information Department, Minister's Secretariat, Ministry of Health, Labor and Welfare. Vital statistics of Japan. Tokyo, 1983.

40. Statistics and Information Department, Minister's Secretariat, Ministry of Health, Labor and Welfare. Vital statistics of Japan. Tokyo, 1984.

41. Statistics and Information Department, Minister's Secretariat, Ministry of Health, Labor and Welfare. Vital statistics of Japan. Tokyo, 1985.

42. Statistics and Information Department, Minister's Secretariat, Ministry of Health, Labor and Welfare. Vital statistics of Japan. Tokyo, 1986.

43. Statistics and Information Department, Minister's Secretariat, Ministry of Health, Labor and Welfare. Vital statistics of Japan. Tokyo, 1987.

44. Statistics and Information Department, Minister's Secretariat, Ministry of Health, Labor and Welfare. Vital statistics of Japan. Tokyo, 1988.

45. Statistics and Information Department, Minister's Secretariat, Ministry of Health, Labor and Welfare. Vital statistics of Japan. Tokyo 1989.

46. Statistics and Information Department, Minister's Secretariat, Ministry of Health, Labor and Welfare. Vital statistics of Japan. Tokyo, 1990.

47. Statistics and Information Department, Minister's Secretariat, Ministry of Health, Labor and Welfare. Vital statistics of Japan. Tokyo, 1991.

48. Statistics and Information Department, Minister's Secretariat, Ministry of Health, Labor and Welfare. Vital statistics of Japan. Tokyo, 1992

49. Statistics and Information Department, Minister's Secretariat, Ministry of Health, Labor and Welfare. Vital statistics of Japan. Tokyo, 1993.

50. Statistics and Information Department, Minister's Secretariat, Ministry of Health, Labor and Welfare. Vital statistics of Japan. Tokyo, 1994.

51. Statistics and Information Department, Minister's Secretariat, Ministry of Health, Labor and Welfare. Vital statistics of Japan. Tokyo 1995.

52. Statistics and Information Department, Minister's Secretariat, Ministry of Health, Labor and Welfare. Vital statistics of Japan. Tokyo, 1996.

53. Statistics and Information Department, Minister's Secretariat, Ministry of Health, Labor and Welfare. Vital statistics of Japan. Tokyo, 1997.

54. Statistics and Information Department, Minister's Secretariat, Ministry of Health, Labor and Welfare. Vital statistics of Japan. Tokyo, 
1998.

55. Statistics and Information Department, Minister's Secretariat, Ministry of Health, Labor and Welfare. Vital statistics of Japan. Tokyo, 1999.

56. Statistics and Information Department, Minister's Secretariat, Ministry of Health, Labor and Welfare. Vital statistics of Japan. Tokyo, 2000.

57. Statistics and Information Department, Minister's Secretariat, Ministry of Health, Labor and Welfare. Vital statistics of Japan. Tokyo, 2001.

58. Statistics and Information Department, Minister's Secretariat, Ministry of Health, Labor and Welfare. Vital statistics of Japan. Tokyo, 2002.

59. Statistic Bureau, Ministry of Public Management, Home Affairs, Posts and Telecommunications. Population census of Japan. Tokyo, 1951.

60. Statistic Bureau, Ministry of Public Management, Home Affairs, Posts and Telecommunications. Population census of Japan. Tokyo, 1956.

61. Statistic Bureau, Ministry of Public Management, Home Affairs, Posts and Telecommunications. Population census of Japan. Tokyo, 1961.

62. Statistic Bureau, Ministry of Public Management, Home Affairs, Posts and Telecommunications. Population census of Japan. Tokyo, 1966.

63. Statistic Bureau, Ministry of Public Management, Home Affairs, Posts and Telecommunications. Population census of Japan. Tokyo, 1971.

64. Statistic Bureau, Ministry of Public Management, Home Affairs, Posts and Telecommunications. Population census of Japan. Tokyo, 1976.

65. Statistic Bureau, Ministry of Public Management, Home Affairs, Posts and Telecommunications. Population census of Japan. Tokyo, 1981.

66. Statistic Bureau, Ministry of Public Management, Home Affairs, Posts and Telecommunications. Population census of Japan. Tokyo, 1986.

67. Statistic Bureau, Ministry of Public Management, Home Affairs, Posts and Telecommunications. Population census of Japan. Tokyo, 1991.

68. Statistic Bureau, Ministry of Public Management, Home Affairs, Posts and Telecommunications. Population census of Japan. Tokyo, 1996.

69. Statistic Bureau, Ministry of Public Management, Home Affairs, Posts and Telecommunications. Population census of Japan. Tokyo, 2001.

70. Statistic Bureau, Management and Coordination Agency, Government of Japan. Annual report on current population estimates. Tokyo, 1951.

71. Statistic Bureau, Management and Coordination Agency, Government of Japan. Annual report on current population estimates. Tokyo, 1952.

72. Statistic Bureau, Management and Coordination Agency, Government of Japan. Annual report on current population estimates. Tokyo, 1953.

73. Statistic Bureau, Management and Coordination Agency, Government of Japan. Annual report on current population estimates. Tokyo, 1954.

74. Statistic Bureau, Management and Coordination Agency, Government of Japan. Annual report on current population estimates. Tokyo, 1955.

75. Statistic Bureau, Management and Coordination Agency, Government of Japan. Annual report on current population estimates. Tokyo, 1956.

76. Statistic Bureau, Management and Coordination Agency, Government of Japan. Annual report on current population estimates. Tokyo, 1957.

77. Statistic Bureau, Management and Coordination Agency, Government of Japan. Annual report on current population estimates. Tokyo, 1958.

78. Statistic Bureau, Management and Coordination Agency, Government of Japan. Annual report on current population estimates. Tokyo, 1959.

79. Statistic Bureau, Management and Coordination Agency, Government of Japan. Annual report on current population estimates. Tokyo, 1960.

80. Statistic Bureau, Management and Coordination Agency, Government of Japan. Annual report on current population estimates. Tokyo, 1961.

81. Statistic Bureau, Management and Coordination Agency, Govern- ment of Japan. Annual report on current population estimates. Tokyo, 1962.

82. Statistic Bureau, Management and Coordination Agency, Government of Japan. Annual report on current population estimates. Tokyo, 1963.

83. Statistic Bureau, Management and Coordination Agency, Government of Japan. Annual report on current population estimates. Tokyo, 1964.

84. Statistic Bureau, Management and Coordination Agency, Government of Japan. Annual report on current population estimates. Tokyo, 1965.

85. Statistic Bureau, Management and Coordination Agency, Government of Japan. Annual report on current population estimates. Tokyo, 1966.

86. Statistic Bureau, Management and Coordination Agency, Government of Japan. Annual report on current population estimates. Tokyo, 1967.

87. Statistic Bureau, Management and Coordination Agency, Government of Japan. Annual report on current population estimates. Tokyo, 1968.

88. Statistic Bureau, Management and Coordination Agency, Government of Japan. Annual report on current population estimates. Tokyo, 1969.

89. Statistic Bureau, Management and Coordination Agency, Government of Japan. Annual report on current population estimates. Tokyo, 1970.

90. Statistic Bureau, Management and Coordination Agency, Government of Japan. Annual report on current population estimates. Tokyo, 1971.

91. Statistic Bureau, Management and Coordination Agency, Government of Japan. Annual report on current population estimates. Tokyo, 1972.

92. Statistic Bureau, Management and Coordination Agency, Government of Japan. Annual report on current population estimates. Tokyo, 1973.

93. Statistic Bureau, Management and Coordination Agency, Government of Japan. Annual report on current population estimates. Tokyo, 1974.

94. Statistic Bureau, Management and Coordination Agency, Government of Japan. Annual report on current population estimates. Tokyo, 1975.

95. Statistic Bureau, Management and Coordination Agency, Government of Japan. Annual report on current population estimates. Tokyo, 1976.

96. Statistic Bureau, Management and Coordination Agency, Government of Japan. Annual report on current population estimates. Tokyo, 1977.

97. Statistic Bureau, Management and Coordination Agency, Government of Japan. Annual report on current population estimates. Tokyo, 1978.

98. Statistic Bureau, Management and Coordination Agency, Government of Japan. Annual report on current population estimates. Tokyo, 1979.

99. Statistic Bureau, Management and Coordination Agency, Government of Japan. Annual report on current population estimates. Tokyo, 1980.

100. Statistic Bureau, Management and Coordination Agency, Government of Japan. Annual report on current population estimates. Tokyo, 1981.

101. Statistic Bureau, Management and Coordination Agency, Government of Japan. Annual report on current population estimates. Tokyo, 1982.

102. Statistic Bureau, Management and Coordination Agency, Government of Japan. Annual report on current population estimates. Tokyo, 1983.

103. Statistic Bureau, Management and Coordination Agency, Government of Japan. Annual report on current population estimates. Tokyo, 1984.

104. Statistic Bureau, Management and Coordination Agency, Government of Japan. Annual report on current population estimates. Tokyo, 1985.

105. Statistic Bureau, Management and Coordination Agency, Government of Japan. Annual report on current population estimates. Tokyo, 1986.

106. Statistic Bureau, Management and Coordination Agency, Government of Japan. Annual report on current population estimates. Tokyo, 1987.

107. Statistic Bureau, Management and Coordination Agency, Government of Japan. Annual report on current population estimates. Tokyo, 1988. 
108. Statistic Bureau, Management and Coordination Agency, Government of Japan. Annual report on current population estimates. Tokyo, 1989.

109. Statistic Bureau, Management and Coordination Agency, Government of Japan. Annual report on current population estimates. Tokyo, 1990.

110. Statistic Bureau, Management and Coordination Agency, Government of Japan. Annual report on current population estimates. Tokyo, 1991.

111. Statistic Bureau, Management and Coordination Agency, Government of Japan. Annual report on current population estimates. Tokyo, 1992.

112. Statistic Bureau, Management and Coordination Agency, Government of Japan. Annual report on current population estimates. Tokyo, 1993.

113. Statistic Bureau, Management and Coordination Agency, Government of Japan. Annual report on current population estimates. Tokyo, 1994.

114. Statistic Bureau, Management and Coordination Agency, Government of Japan. Annual report on current population estimates. Tokyo, 1995.

115. Statistic Bureau, Management and Coordination Agency, Government of Japan. Annual report on current population estimates. Tokyo, 1996.

116. Statistic Bureau, Management and Coordination Agency, Government of Japan. Annual report on current population estimates. Tokyo, 1997.

117. Statistic Bureau, Management and Coordination Agency, Government of Japan. Annual report on current population estimates. Tokyo, 1998.

118. Statistic Bureau, Management and Coordination Agency, Government of Japan. Annual report on current population estimates. Tokyo, 1999.

119. Statistic Bureau, Management and Coordination Agency, Government of Japan. Annual report on current population estimates. Tokyo, 2000

120. Statistic Bureau, Management and Coordination Agency, Government of Japan. Annual report on current population estimates. Tokyo, 2001.

121. Daly LE, Bourke GJ. Interpretation and uses of medical statistics, 5th edn. London: Blackwell Science, 2000: 248-251.

122. Armitage P, Berry G, Matthews JNS. Statistical methods in medical research, 4th edn. London: Blackwell Science, 2002.
123. The study circle for health and nutrition information: The national nutrition survey in Japan. Daiichi Shuppan Publishing Company Ltd (in Japanese). Tokyo, 2001.

124. Statistics and Information Department, Minister's Secretariat, Ministry of Health, Labor and Welfare. Patient survey.

125. Kawasaki T, Kambayashi J-i, Sakon M. Hyperlipidemia: A novel etiologic factor in deep vein thrombosis. Thromb Res 1995; 79: $147-151$.

126. Kawasaki T, Kambayashi J-i, Ariyoshi H, Sakon M, Suehisa E, Monden M. Hypercholesterolemia as a risk factor for deep-vein thrombosis. Thromb Res 1997; 88: 67-73.

127. de Lorgeril M, Salen P, Martin JL, Monjaud I, Delaye J, Mamelle $\mathrm{N}$. Mediterranean diet, traditional risk factors, and the rate of cardiovascular complications after myocardial infarction: Final report of the Lyon Diet Heart Study. Circulation 1999; 99: 779-785.

128. Kumasaka N, Sakuma M, Shirato K. Clinical features and predictors of in-hospital mortality in patients with acute and chronic pulmonary thromboembolism. Intern Med 2000; 39: 1038-1043.

129. Nakamura M, Fujioka H, Yamada N, Sakuma M, Okada O, Nakanishi $\mathrm{N}$, et al. Clinical characteristics of acute pulmonary thromboembolism in Japan: Results of a multicenter registry in Japanese Society of Pulmonary Embolism Research. Clin Cardiol 2001; 24: $132-138$.

130. Kimamukai O, Sakuma M, Takahashi T, Shirato K. Incidence and character of pulmonary thromboembolism in Japan. Circ J 2002; 66(Suppl I): 729.

131. Klatsky AL, Armstrong MA, Poggi J. Risk of pulmonary embolism and/or deep venous thrombosis in Asian-Americans. Am J Cardiol 2000; 85: 1334-1337.

132. Rees DC, Cox M, Clegg JB. World distribution of factor V Leiden. Lancet 1995; 346: 1133-1134.

133. Rosendaal FR, Doggen CJM, Zivelin A, Arruda VR, Aiach M, Siscovick DS, et al. Geographic distribution of the 20210G to A prothrombin variant. Thromb Haemost 1998; 79: 706-708.

134. Seki T, Okayama H, Kumagai T, Kumasaka N, Sakuma M, Isoyama $\mathrm{S}$, et al. Arg506Gli mutation of the coagulation V gene not detected in Japanese pulmonary thromboembolism. Heart Vessels 1998; 13: $195-198$.

135. Miyata T, Kawasaki T, Fujimura H, Uchida K, Tsushima M, Kato $\mathrm{H}$. The prothrombin gene G20210A mutation is not found among Japanese patients with deep vein thrombosis and healthy individuals. Blood Coagul Fibrinolysis 1998; 9: 451-452. 